\title{
Soybean Bioactive Peptides and Their Functional Properties
}

\author{
Cynthia Chatterjee ${ }^{1,2}$, Stephen Gleddie ${ }^{2}$ and Chao-Wu Xiao ${ }^{1,3, *}$ \\ 1 Nutrition Research Division, Food Directorate, Health Products and Food Branch, Health Canada, \\ Banting Research Centre, 251 Sir Frederick Banting Drive, Ottawa, ON K1A 0K9, Canada; \\ cynthia.chatterjee@canada.ca \\ 2 Ottawa Research \& Development Centre, Central Experimental Farm, Agriculture and Agri-Food Canada, \\ 960 Carling Avenue Building\#21, Ottawa, ON K1A 0C6, Canada; steve.gleddie@agr.gc.ca \\ 3 Food and Nutrition Science Program, Department of Chemistry, Carleton University, 1125 Colonel By Drive, \\ Ottawa, ON K1S 5B6, Canada \\ * Correspondence: chaowu.xiao@canada.ca; Tel.: +1-613-558-7865; Fax: +1-613-948-8470
}

Received: 26 July 2018; Accepted: 29 August 2018; Published: 1 September 2018

\begin{abstract}
Soy consumption has been associated with many potential health benefits in reducing chronic diseases such as obesity, cardiovascular disease, insulin-resistance/type II diabetes, certain type of cancers, and immune disorders. These physiological functions have been attributed to soy proteins either as intact soy protein or more commonly as functional or bioactive peptides derived from soybean processing. These findings have led to the approval of a health claim in the USA regarding the ability of soy proteins in reducing the risk for coronary heart disease and the acceptance of a health claim in Canada that soy protein can help lower cholesterol levels. Using different approaches, many soy bioactive peptides that have a variety of physiological functions such as hypolipidemic, anti-hypertensive, and anti-cancer properties, and anti-inflammatory, antioxidant, and immunomodulatory effects have been identified. Some soy peptides like lunasin and soymorphins possess more than one of these properties and play a role in the prevention of multiple chronic diseases. Overall, progress has been made in understanding the functional and bioactive components of soy. However, more studies are required to further identify their target organs, and elucidate their biological mechanisms of action in order to be potentially used as functional foods or even therapeutics for the prevention or treatment of chronic diseases.
\end{abstract}

Keywords: soy protein; soy peptides; bioactives; functional property; chronic diseases; biomarkers

\section{Introduction}

Soybean (Glycine max) was cultivated in Asia for nearly 5000 years, first in China, then in Japan. It was introduced to Europe in the 18th century and then to the United States in the 19th century [1-3]. Soybean has been an important economic crop in the United States since the 1940s. Currently the United States is the leading soy producer and accounts for over $30 \%$ of the world's production $[3,4]$. The popularity of soy foods or products has been rising in North America over the last decades, particularly after the U.S. Food and Drug Administration (FDA) approved the food health claim linking soy protein to the reduction of the risk for coronary heart disease in 1999 [4-7]. Soybean is a rich source of high-quality proteins containing all the essential amino acids found in animal proteins without cholesterol and with less saturated fat.

Epidemiological studies have associated soy consumption with potential benefits in reducing the risk for chronic diseases such as obesity, cardiovascular disease, insulin-resistance/type II diabetes, certain type of cancers, and immune disorders [3,5,6,8-11]. Soy proteins and their associated 
phytochemicals, mainly isoflavones, are believed to be responsible for these health benefits. However, the specific functional or bioactive component(s) in soy have not been identified nor their mechanism of action well understood. In recent years, research has focused more on biologically active or "bioactive" peptides derived from soybeans from processes mimicking gastrointestinal digestion. This paper summarizes the current knowledge about the soybean bioactive peptides and their roles in the modulation of physiological functions or prevention of chronic diseases.

\section{Soy Composition and Major Bioactives}

Soybeans are generally composed of $\sim 35-40 \%$ protein, $\sim 20 \%$ lipids, $\sim 9 \%$ dietary fiber, and $\sim 8.5 \%$ moisture based on the dry weight of mature raw seeds [3]. Their compositions vary with the variety and with the location and climate of the planting. The major soy components that have been shown to have biological activity include proteins or peptides, isoflavones, saponins, and protease inhibitors $[8,12]$.

\subsection{Soy Proteins and Subunits}

The two major storage proteins, $\beta$-conglycinin ( $\beta C G, 7 S$ ) and glycinin (11S), comprise $80-90 \%$ of the total protein in soybean $[5,6,13,14]$. $\beta C G$ is composed of $\alpha^{\prime}, \alpha$, and $\beta$ subunits, whereas glycinin is composed of acidic (A) and basic (B) subunits: A1aB2, A1bB1b, A2B1a, A3B4, and A5A4B3 [6,12]. Minor proteins in soybean include $2 \mathrm{~S}, 9 \mathrm{~S}$, and $15 \mathrm{~S}$ storage proteins; lectin; and Kunitz and Bowman-Birk (BBI) protease inhibitors [14]. Soy proteins with different ratios of $\beta C G$ and glycinin are believed to have different nutritional and physiological effects $[15,16]$. Soy proteins with varying subunit compositions have also been shown to have significantly different functional properties in relation to quality, yield, and texture in tofu production [17]. Bioactive peptides are inactive when they are part of the parent protein sequence, but become activated upon release by enzymatic processing, gastrointestinal digestion, food processing, or fermentation $[9,10,16]$. They are usually 2 to 20 amino acids in length and are absorbed by the intestines into the blood circulation to exert systemic or local physiological effects in target tissues $[9,11,16]$. Maebuchi et al. has demonstrated that human intestinal absorption of $11 \mathrm{~S}$ peptides resulted in significantly greater increase in venous blood amino acid concentrations than did $11 S$ globulin or amino acid mixture when administered as a beverage [18]. This difference was particularly notable for aromatic and branched-chain amino acids, suggesting that hydrolyzed soy protein is faster and more efficiently absorbed in humans [18].

\subsection{Soy Isoflavones}

The other major bioactive compounds in soybeans are the isoflavones, which are associated with the soy proteins. Isoflavones are phytochemicals, often referred to as phytoestrogens because they structurally resemble $17 \beta$-estradiol, and can bind both estrogen receptors $\alpha$ and $\beta(E R \alpha / \beta)$, but have a higher affinity for ER $\beta$ [19-22]. They possess both estrogenic and anti-estrogenic properties as shown in cell culture and clinical studies. Most of the isoflavones are naturally present in soybeans as glycosides, genistin, diadzin, and glycetin. However, upon digestion or fermentation by $\beta$-glucosidases they are converted to the bioactive form, aglycones: genistein, diadzein, and glycetein [6,8]. Soy isoflavones have been linked with beneficial effects in preventing heart disease, diabetes, menopausal symptoms, osteoporosis, and prostate and breast cancers [23-26] in humans because of their hormonal and antioxidant properties [23,27]. The large variation in abundance of each isoflavone in soybeans and soy foods and their bioavailability results in inconsistent physiological functions found among different studies $[3,8,23,25,26]$.

\subsection{Soy Saponins}

A minor bioactive component in soybeans are the saponins which are amphiphilic oleanane triterpenoid glycosides with polar sugar chains conjugated to a nonpolar pentacyclic ring [28]. It is suggested that saponins have anti-inflammatory, anti-carcinogenic, antimicrobial, and hepato- and cardio-protective effects [28]. The effect of saponins is not further discussed in this review, which mainly focuses on bioactive soy peptides. 


\section{Methods of Bioactive Peptide Production}

Soy bioactive peptides are small protein fragments produced by enzymatic hydrolysis, fermentation, food processing, and gastrointestinal digestion of larger soybean proteins $[11,29]$ and are associated with a multitude of beneficial metabolic effects [16]. The peptide production and composition by different methods are affected by the enzymes (in vitro enzymatic hydrolysis) or bacteria (in fermentation) used and also related to the type of soy proteins.

\subsection{Gastrointestinal Digestion}

In its simplest form, soy bioactive peptides are released upon ingestion and digestion of soybeans by acid and digestive enzymes from the stomach, small intestine, and pancreas such as pepsin, trypsin, chymotrypsin, and pancreatin. These small peptides are absorbed through the walls of the small intestine into the bloodstream where they can have systemic effects or target specific tissues [30-32].

\subsection{In Vitro Enzymatic Hydrolysis}

In vitro enzymatic hydrolysis is applied commercially in larger volumes, which can have better quality control and are more effective and stable in obtaining peptides with specific molecular weight and peptide profiles [16]. In vitro enzymatic hydrolysis can also utilize a combination of specific and nonspecific proteases such as pepsin, trypsin, chymotrypsin, papain, and peptidase to obtain peptides from digestion of soy proteins under their optimal $\mathrm{pH}$ and temperature conditions.

\subsection{Food Processing}

Bioactive peptides can be formed during food processing because of structural or chemical alterations. For example, $\mathrm{pH}$ modifications or chemical treatments may lead to the modification of amino acids, altering functional properties [33]. Improved functionality can lead to improvements in digestibility, protein or peptide enrichment, or reduction of trypsin inhibitor activity, which can arise from acylation, glycosylation, phosphorylation, reductive alkylation, succinylation, or lipophilization [33]. Common food processing techniques include heat treatment, $\mathrm{pH}$ modification, protein separation, ultra-high-pressure processing, and storage conditions [33,34].

\subsection{Bacterial Fermentation}

Traditionally, Asian countries like Korea, China, and Japan have been consuming fermented soybean foods such as soy sauce, soy paste, natto, tempeh, and miso for a long time [3]. Fermentation is an efficient and cost-effective method for generating bioactive peptides and food-grade hydrolyzed proteins through microbial activity or microbial enzymatic activity [16,34]. A large group of bacteria known as lactic acid bacteria found in the upper gastrointestinal tract are frequently used in fermentation to produce bioactive peptides [16]. However, fermentation may not fully hydrolyze soybean proteins with post-translational modification and complex tertiary structures. It is necessary to supply additional enzymes such as pronase, trypsin, and plasma proteases to produce smaller peptides with better bioactivity $[16,34,35]$. In addition, fermentation plays an important role in texture and flavor development [16].

\section{Soy Bioactive Peptides and Their Properties}

Over the last decade or so, the focus of soy research has shifted to the identification and characterization of bioactive peptides and their corresponding physiological functions. Numerous soy peptides with widespread beneficial physiological effects have been identified as shown in Table 1 . These include lipid lowering (hypocholesterolemic, hypotriglyceridemic, anti-obesity) to anti-diabetic, anti-cancer, hypotensive, anti-inflammatory, and antioxidant in a variety of experimental models. 
Table 1. Soy bioactive peptides and their properties.

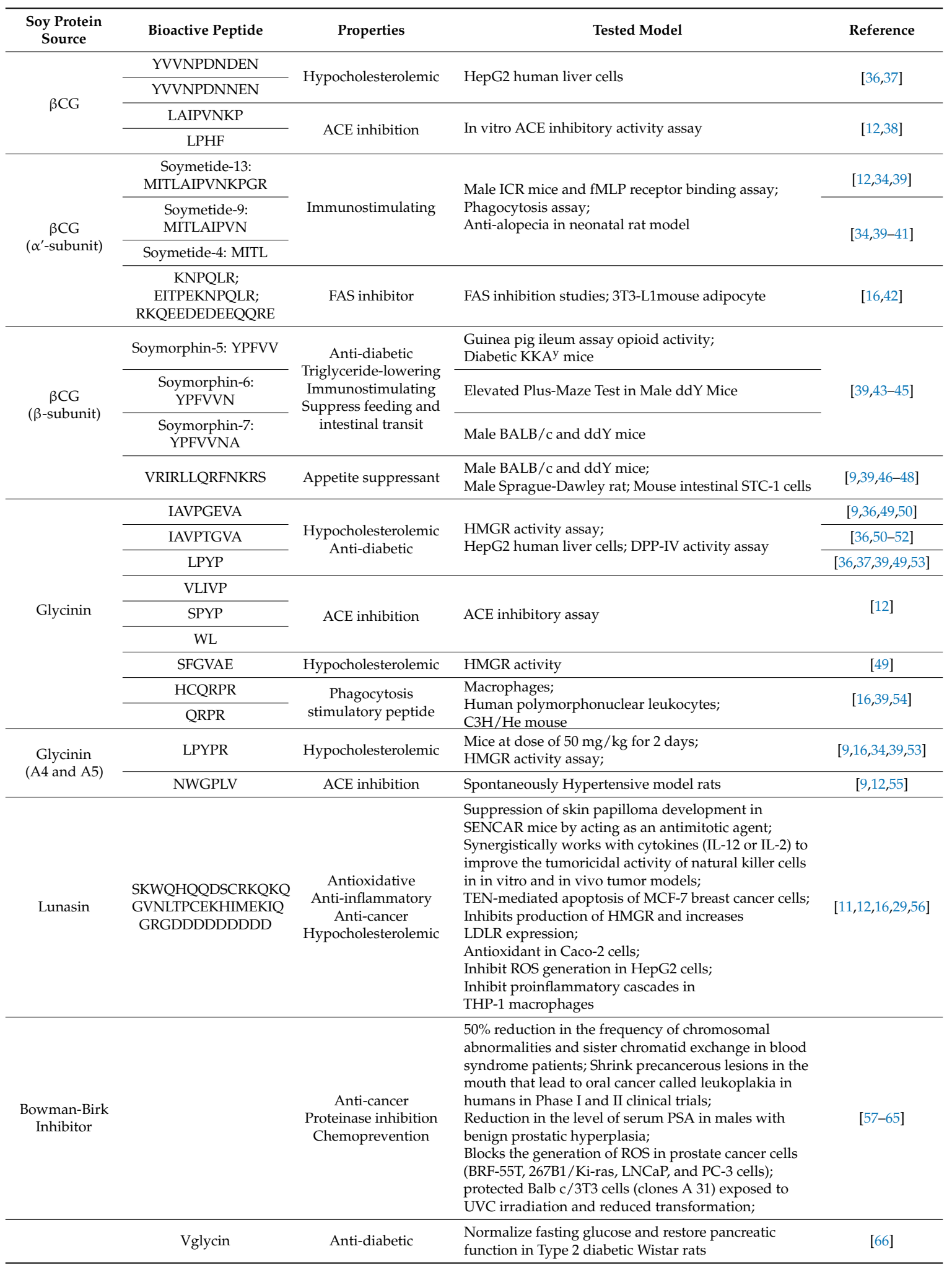


Table 1. Cont.

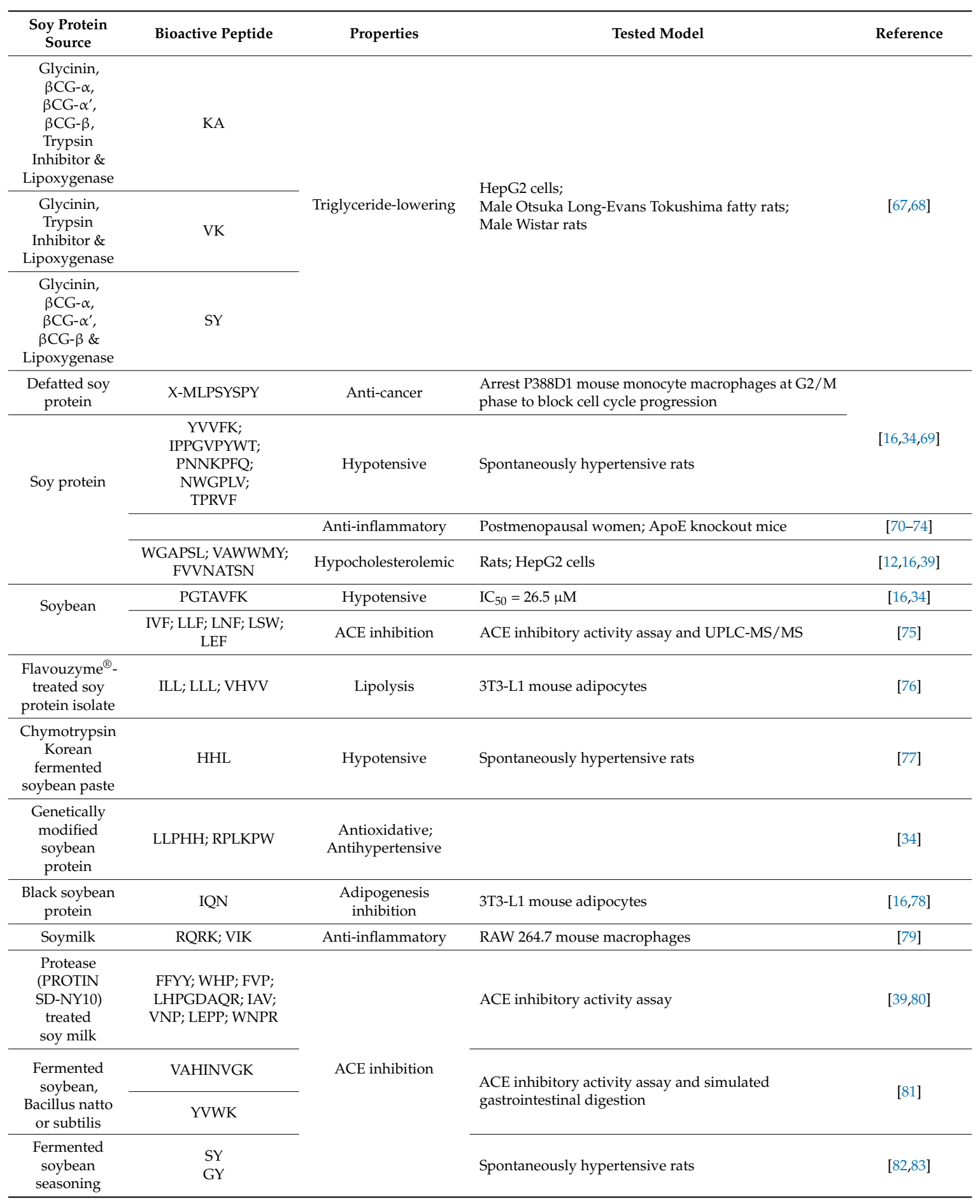

\subsection{Hypolipidemic}

The best studied bioactivity of soy peptides is their hypolipidemic property. Many soy peptides have been identified to lower cholesterol and triglycerides, and to suppress fat synthesis and storage in different experimental systems. LPYPR from the glycinin subunit of the soybean was one of the initial hypocholesterolemic peptides discovered by Yoshikawa et al. (2000). Administration of this peptide at a dose of $50 \mathrm{mg} / \mathrm{kg}$ of body weight without isoflavones for 2 days reduced both serum total and low-density lipoprotein (LDL) cholesterol in rats by $25 \%$ [53]. Subsequent studies further showed that, more specifically, LPYP was hypocholesterolemic [84] and acting as a competitive inhibitor of 
3-hydroxy-3-methylglutaryl CoA reductase (HMGR), the major rate-limiting enzyme in cholesterol biosynthesis [49]. This peptide increased LDL uptake in cultured liver cells through activating the LDL receptor (LDLR)-sterol regulatory element-binding protein 2 (SREBP2) pathway [36].

Two other cholesterol-lowering peptides derived from glycinin are IAVPGEVA and IAVPTGVA [50,51]. Similar to LPYP, these peptides were shown to inhibit HMGR activity in cultured HepG2 cells and promote LDL uptake via the LDLR-SREBP2 pathway [36,49]. Lammi et al. uncovered two hypocholesterolemic peptides-YVVNPDNDEN and YVVNPDNNEN—derived from soy $\beta C G$, which also modulate cholesterol by an identical mechanism [37]. Some other hypocholesterolemic soy peptides include lunasin (2S) peptides [29], SFGVAE [49], WGAPSL [12,16], LLPHH [34], RPLKPW [34], VAWWMY [85-87], and FVVNATSN [88].

Moreover, several hypotriglyceridemic di-peptides have been identified from soybean components. These are KA (from glycinin, $\beta C G$, trypsin inhibitor, and lipoxygenase), VK (from glycinin, trypsin inhibitor, and lipoxygenase), and SY (from glycinin, $\beta C G$, and lipoxygenase) [67]. $\beta C G$ was shown to inhibit fatty acid synthesis in the liver leading to a reduction in serum triglycerides in rats [68]. Further studies have identified that the peptides KNPQLR, EITPEKNPQLR, and RKQEEDEDEEQQRE in this protein were able to suppress fatty acid synthase (FAS) activity [16,42]. ßCG subunits demonstrated a better ability to reduce lipid levels in mouse 3T3-L1 adipocytes by embedding more active peptides in the cells than glycinin subunits [89], and to suppress lipid accumulation by downregulating lipoprotein lipase and FAS [90]. Peptides ILL, LLL, and VHVV derived from Flavourzyme ${ }^{\circledR}$-treated soy protein isolate showed lipolysis-stimulating activity in 3T3-L1 mouse adipocytes $[76,91]$.

\subsection{Anti-Diabetic}

Obesity and hyperlipidemia are often associated with insulin resistance and type II diabetes leading to the metabolic disease phenotype. Interestingly, many soy peptides with hypolipidemic function also possess anti-diabetic activity in different experimental models. For example, the hypocholesterolemic soy peptides LPYP, IAVPGEVA, and IAVPTGVA also improved glucose metabolism by increasing glucose uptake in cultured hepatic cells via glucose transporters (GLUT) 1 and 4 [36,92]. Further in vitro and in silico studies demonstrated that peptide IAVPTGVA was an efficient inhibitor of dipeptidyl peptidase IV (DPP-IV), a serine exopeptidase. DPP-IV is responsible for the hydrolysis of glucagon-like peptide and glucose-dependent insulinotropic polypeptide which are critical for maintaining glucose homeostasis [52]. Although the peptides YVVNPDNDEN and YVVNPDNNEN had similar hypocholesterolemic activity as IAVPTGVA, they were ineffective at inhibiting DPP-IV due to their longer peptide sequence and lack of Pro as the fourth N-terminal residue [52].

Both soy protein and isoflavones have been linked with improvements in diabetic rodent models [93-95] such as lowered serum glucose levels, increased insulin secretion, and reduced fasting plasma glucose. However, fermented soybean products containing soy peptides like natto and chungkookjang may be even better in the prevention of the onset of type II diabetes in human and mouse models $[10,96-98]$. Consumption of a diet containing soy protein $(35 \%$ animal protein, $35 \%$ soy protein, and $30 \%$ other plant proteins) for 6 weeks by women aged $18-40$ years (at week 24-28 of gestation) with gestational diabetes mellitus $(n=34)$ was associated with significant improvements in fasting plasma glucose, serum insulin levels, homeostasis model of assessment-insulin resistance, and quantitative insulin sensitivity check index compared with the control diet group consisting of $70 \%$ animal and 30\% plant proteins $(n=34)$ [99]. Studies by Oliva et al. demonstrated that dyslipidemic insulin-resistant Wistar rats fed a sucrose-rich diet supplemented with soy protein had decreased hepatic triglyceride and cholesterol storage and steatosis, functional muscle glucose transporter GLUT4, and normalized glucose-6-phosphate and glycogen levels [100]. In spontaneously diabetic Goto-Kakikazi rats, consumption of $\beta C G$ specifically improved muscle glucose uptake with higher plasma adiponectin, increased GLUT4 translocation, and phosphorylated 
adenosine monophosphate-activated protein kinase (AMPK) [101]. Similarly, soymorphin-5 (YPFVV), a soy-derived $\mu$-opioid peptide derived from the $\beta$-subunit of the $\beta C G$ lowered glucose and triglyceride levels in diabetic KKAy mice through activation of adiponectin and peroxisome proliferator-activated receptor $\alpha(\operatorname{PPAR} \alpha)$ [43]. Roblet et al. utilized electrodialysis with an ultrafiltration membrane to isolate low-molecular-weight (300-500 Da) soy peptides from a complex soy mixture [102]. This peptide fraction improved glucose uptake in cultured rat muscle cells through activation of AMPK by phosphorylation [102]. Another study showed that the soybean peptide, Vglycin, is resistant to digestive enzymes and has anti-diabetic function in type II diabetic Wistar rats [66]. Vglycin comprises 37 amino acids with 6 half-cysteines that are part of 3 pairs of disulfide bonds. When administered to diabetic Wistar rats for 4 weeks, it normalized fasting glucose levels, increased insulin sensitivity, and restored insulin signaling and pancreatic function [66].

\subsection{Anti-Hypertensive}

High blood pressure or hypertension is another risk factor for coronary heart disease. Interestingly, antihypertensive peptides are the most commonly occurring and best studied bioactive peptides in foods $[11,16]$. Antihypertensive peptides function by blocking angiotensin-converting enzyme (ACE), which modulates the rennin-angiotensin system, thereby regulating blood pressure [11,34]. The dipeptidyl carboxypeptidase activity of ACE converts the decapeptide angiotensin I into the vasoconstricting octapeptide angiotensin II, resulting in increased blood pressure [11]. Traditional Asian fermented soybean foods such as soybean paste [77], soy sauce [103], natto [104], and tempeh [105] are rich in ACE inhibitory peptides [81,106]. Korean fermented soybean paste treated with chymotrypsin contains the hypotensive tripeptide, HHL $[12,16]$, while soybean fermented with Bacillus natto or Bacillus subtilis was shown to contain two ACE inhibitor peptides, VAHINVGZK and YVWK [16,34]. Fermented soybean seasoning was shown to have a higher ACE inhibitory activity compared with soy sauce [82] and this was attributed to the peptides SY and GY, which decreased hypertension in salt-sensitive Dahl rats by suppressing the renin-angiotensin system and lowering serum aldosterone levels [83]. Okara, a soy pulp extract that is a by-product of tofu production, has been shown to have ACE inhibitory activity due to the presence of some small antihypertensive peptides [107].

The other antihypertensive soy peptides include PGTAVFK, IVF, LLF, LNF, LSW, LEF, YVVFK, IPPGVPYWT, PNNKPFQ, NWGPLV, and TPRVF [16,34]. Treatment of soy milk with the industrial protease PROTIN SD-NY10 produced FFYY, WHP, FVP, LHPGDAQR, IAV, VNP, LEPP, and WNPR peptides that had enhanced ACE inhibitory activity compared with regular soy milk [80]. In soy $\beta C G$, LAIPVNKP and LPHF were demonstrated to have ACE inhibitory activity, while glycinin was found to contain the ACE inhibitory peptides VLIVP, SPYP, and WL, and more specifically, the A4 and A5 subunits of glycinin comprised the antihypertensive peptide sequence of NWGPLV [9,12]. It has been revealed that some structural similarities exist among the bioactive peptides with blood pressure lowering properties. The presence of Pro or hydroxyl-Pro at the C-terminus made the peptides generally resistant to degradation by digestive enzymes, while Pro, Lys, or Arg were preferred at the C-terminus for ACE inhibitory potency [9,34]. It was also observed that dipeptides with a C-terminal Tyr had higher antihypertension effect than dipeptides with C-terminal Phe [9].

\subsection{Anti-Cancer}

Soy isoflavones have drawn much scrutiny over the years in terms of their role in cancer from both a promotion and prevention standpoint [3,6]. However, soy peptides have also been identified in different experimental systems to have anti-cancer properties $[11,12,16,29,56]$. Back in 2000, Kim et al. purified the hydrophobic peptide X-MLPSYSPY from defatted soy protein that arrested the cell cycle progression of murine lymphoma cells (P388D1) at G2/M phase [69]. Further studies have shown that most of the anti-cancer soy peptides belong to the minor $2 \mathrm{~S}$ fraction of soybean proteins: lunasin and BBI $[12,16,29,56-58]$. The BBI is a low-molecular-weight protein, can inhibit trypsin and chymotrypsin 
activity, and has been considered as an anti-nutrient for a long time [57,108]. It has demonstrated anti-carcinogenicity in different species including humans and tissue types including colon, liver, esophagus, breast, prostrate, and was considered as an FDA Investigational Drug in 1992 [57,108]. In both Phases I and II human trials, the BBI promised to be a safe cancer chemopreventive agent that prevents and suppresses malignant transformation and carcinogenesis at doses from 800 to 2000 chymotrypsin inhibitor units $[108,109]$. The mechanism by which BBI exerts its anti-cancer activity involves apoptosis through reactive-oxygen-species-induced mitochondrial damage after proteasomal inhibition and anti-angiogenesis [110-113].

Lunasin (SKWQHQQDSCRKQKQGVNLTPCEKHIMEKIQGRGDDDDDDDDD) is another chemopreventive peptide that is closely associated with the BBI. It is 43 residues long with a C-terminal of 9 aspartic acid residues and cell adhesion motif, RGD that enables binding to non-acetylated H3 and $\mathrm{H} 4$ histones to prevent their acetylation, providing its anti-carcinogenic activity [16,34]. Park et al. showed that the BBI has a function of protecting lunasin from gastrointestinal degradation when soy protein is consumed orally [58]. Lunasin decreased skin tumor incidence in the SENCAR mice skin cancer model by $\sim 70 \%$ when topically applied at a dose of $250 \mu \mathrm{g}$, and promoted colony suppression of mammalian cells induced by carcinogens and viral oncogenes E1A and RAS by 30-43\% [11,12,114-117]. However, its effects on human breast cancer cell line MCF-7 appear to be inconsistent. Lunasin did not inhibit the growth rate of MCF-7 and mouse fibroblase NIH 3T3 cancer cells in vitro [117], whereas more recent study showed that lunasin induced apoptosis in MCF-7 cells by upregulation of tumor suppressor PTEN similar to the soy isoflavone genistein [56]. Lunasin is also able to inactivate the tumor suppressor proteins, $\mathrm{Rb}$, p53, and pp32, and competes with the histone acetyltransferases in binding to the core deacetylated histones $\mathrm{H} 3$ and $\mathrm{H} 4$, and switching off the transcription, leading to arrest of the G1/S phase and causing apoptosis [29].

\subsection{Antioxidant and Anti-Inflammatory}

Carcinogenesis and cancer development depend in part on pro-inflammatory, pro-oxidant, and immunosuppressive mechanisms that lead to abnormal growth of tissue. Consequently, proteins and peptides with anti-cancer properties often also exhibit anti-inflammatory and antioxidant effects $[29,70]$. Soy protein with or without isoflavones was shown to reduce oxidative stress and have anti-inflammatory properties by inhibiting nuclear factor-kappa B (NF- $\mathrm{B}$ ) and blocking the secretion of pro-inflammatory cytokines in an oxidative-stress-inducible rat model, a hyperlipidemic mouse model, humans with end-stage renal disease, and healthy women over 70 years of age [70]. Soy milk digested with pepsin and pancreatin produced the bioactive peptides RQRK and VIK, which inhibited lipopolysaccharide-induced inflammation in murine macrophages. These hydrolysates inhibited the production of nitric oxide, interleukin (IL)-1 $\beta$, nitric oxide synthase, and cyclooxygenase-2 [79].

Lunasin's anti-cancer potential arises from its dual anti-oxidative and anti-inflammatory capacity [29]. As an anti-oxidant, lunasin was shown to inhibit 2,20-azino-bis(3-ethylbenzothiazoline-6sulfonic acid) diammonium salt radical scavenger, reactive oxygen species production, and the secretion of pro-inflammatory cytokines (Tumor Necrosis Factor- $\alpha$ and IL-6) in mouse RAW 264.7 macrophages $[29,118]$. It acts as a potent peroxyl and superoxide scavenger, and can prevent glutathione peroxidase and catalase activities [119]. The RGD motif of lunasin was responsible for blocking inflammation in human macrophages by interacting with $\alpha \mathrm{V} \beta 3$ integrin through an Akt-mediating NF- $\kappa B$ pathway [120]. A trial in healthy men demonstrated that ingestion of $50 \mathrm{~g}$ of soy protein resulted in the absorption rate of $\sim 4.5 \%$ of the total lunasin ingested [121]. 


\subsection{Immunomodulatory}

Closely associated with anti-cancer, anti-oxidant, and anti-inflammatory peptides are immunomodulatory peptides. Immunomodulatory peptides boost immune cell functions; for example, natural killer cell activity or cytokine regulation [16]. These peptides have been found in soy protein hydrolysates that are enzymatically digested [34]. The hydrolysates prepared from insoluble soy protein with alcalase had the greatest murine splenic lymphocyte proliferation and phagocytosis capability in peritoneal macrophages [16,122]. The peptides HCGAPA and GAPA from the glycinin component of soy protein hydrolysate stimulated phagocytosis $[39,54]$. The trypsin digests of soy proteins revealed that the sequence MITLAIPVNKPGR was able to stimulate phagocytosis in leukocytes [34,39]. This peptide is derived from the $\alpha^{\prime}$-subunit of $\beta C G$ and was named soymetide and later soymetide-13 since Met at its N-terminus was essential for its activity [34,39]. Some of the C-terminus residues of soymetide-13 could be removed to form soymetide-9 (MITLAIPVN) which had the highest activity. Soymetide-4 (MITL) was the minimal sequence required for its activity [39]. In general, the soymetides had an affinity for the $\mathrm{N}$-formyl-methionyl-leucyl-phenylalanine receptor despite not being formylated at the N-terminus Met $[39,40]$.

\subsection{Neuromodulatory}

The $\beta$-subunit of $\beta C G$ contains the sequence for human $\beta$-casophormin-4 (YPFV), an opioid peptide that has morphine-like activity. This has resulted in the discovery of three peptides with anxiolytic activities: soymorphin-5 (YPFVV), soymorphin-6 (YPFVVN), and soymorphin-7 (YPFVVNA) [44]. These peptides were selective for the $\mu$ opioid receptor and were shown to suppress food intake and small intestinal transit due to the coupling of the receptor to neurotransmitters in mice [45]. In addition, soymorphin-5 was shown to improve glucose and triglyceride levels in a KKAy diabetic mouse model by activating adiponectin and $\operatorname{PPAR} \alpha$, and promoting $\beta$-oxidation and energy expenditure [43]. These peptides may not need to be absorbed into the blood circulation for their anxiolytic effects. The $\beta$-subunit of $\beta C G$ also contains the peptide VRIRLLQRFNKRS (fragment 51-63) which suppressed food intake and gastric emptying in rats by stimulating a mediator of satiety, plasma cholecystokinin, through an extracellular calcium-sensing receptor [46-48].

\section{Conclusions}

Soybean is a promising source of peptides that have a wide range of biological activities such as hypolipidemic, anti-diabetic, anti-hypertensive, anti-cancer, antioxidant, anti-inflammatory, immunostimulatory, and neuromodulatory properties demonstrated in different models. Further studies are warranted for better understanding of their absorption, metabolism, and target tissues, as well as for elucidating their mechanisms of actions. A high quality of human trials will help in this regard as well as address the bioavailability of the peptides. Certain functions of the soy peptides such as the anxiolytic effects of soymorphins may not require their absorption into the blood circulation. However, anti-cancer or hypolipidemic peptides need to be bioavailable to pass through the small intestines into the bloodstream to reach their target tissues. More studies are needed to identify the quantity of the active soybean peptides released by different methods (for example, in vivo or in vitro digestions), and the impact of gender and age on the action or production of bioactive soybean peptides.

Author Contributions: All authors contributed to preparation and revision of the manuscript.

Funding: C.C. is supported by the National Science and Engineering Research Council (NSERC) Visiting Fellowship in Canadian Government Laboratories.

Conflicts of Interest: The authors declare that they have no conflict of interest. 


\section{Abbreviations}

$\begin{array}{ll}\text { ACE } & \text { angiotensin-converting enzyme } \\ \text { Akt } & \text { protein kinase B } \\ \text { AMPK } & \text { adenosine monophosphate-activated protein kinase } \\ \text { ApoE } & \text { apolipoprotein E } \\ \text { BBI } & \text { Bowman-Birk inhibitor } \\ \text { DPP-IV } & \text { dipeptidyl peptidase IV } \\ \text { ER } & \text { estrogen receptor } \\ \text { FAS } & \text { fatty acid synthase } \\ \text { fMLP } & \text { N-formylmethionyl-leucyl-phenylalanine } \\ \text { FDA } & \text { Food and Drug Administration } \\ \text { ICR } & \text { Institute of Cancer Research } \\ \text { IL } & \text { Interleukin } \\ \text { GLUT } & \text { glucose transporters } \\ \text { HMGR } & \text { 3-hydroxy-3-methylglutaryl-CoA reductase } \\ \text { LDL } & \text { low-density lipoprotein } \\ \text { LDLR } & \text { LDL receptor } \\ \text { NF-kB } & \text { nuclear factor kappa B } \\ \text { PPAR } \alpha & \text { peroxisome proliferator-activated receptor } \alpha \\ \text { PSA } & \text { Prostate specific antigen } \\ \text { ROS } & \text { Reactive oxygen species } \\ \text { SREBP2 } & \text { sterol regulatory element-binding protein 2 } \\ \text { UPLC-MS/MS } & \text { Ultra performance liquid chromatography-tandem mass spectrometry } \\ \text { UVC } & \text { Ultraviolet C }\end{array}$

\section{References}

1. Valliyodan, B.; Dan, Q.; Patil, G.; Zeng, P.; Huang, J.; Dai, L.; Chen, C.; Li, Y.; Joshi, T.; Song, L.; et al. Landscape of genomic diversity and trait discovery in soybean. Sci. Rep. 2016, 6, 23598. [CrossRef] [PubMed]

2. Li, Y.; Guan, R.; Liu, Z.; Ma, Y.; Wang, L.; Li, L.; Lin, F.; Luan, W.; Chen, P.; Yan, Z.; et al. Genetic structure and diversity of cultivated soybean (Glycine max (L.) Merr.) landraces in China. Theor. Appl. Genet. 2008, 117, 857-871. [CrossRef] [PubMed]

3. He, F.J.; Chen, J.Q. Consumption of soybean, soy foods, soy isoflavones and breast cancer incidence: Differences between Chinese women and women in Western countries and possible mechanisms. Food Sci. Human Wellness 2013, 2, 146-161. [CrossRef]

4. Huang, H.; Krishnan, H.B.; Pham, Q.; Yu, L.L.; Wang, T.T. Soy and gut microbiota: Interaction and implication for human health. J. Agric. Food Chem. 2016, 64, 8695-8709. [CrossRef] [PubMed]

5. Velasquez, M.T.; Bhathena, S.J. Role of dietary soy protein in obesity. Int. J. Med. Sci. 2007, 4, 72-82. [CrossRef] [PubMed]

6. Xiao, C.W. Health effects of soy protein and isoflavones in humans. J. Nutr. 2008, 138, 1244S-1249S. [CrossRef] [PubMed]

7. Young, V.R. Soy protein in relation to human protein and amino acid nutrition. J. Am. Diet. Assoc. 1991, 91, 828-835. [PubMed]

8. Omoni, A.O.; Aluko, R.E. Soybean foods and their benefits: potential mechanisms of action. Nutr. Rev. 2005, 63, 272-283. [CrossRef] [PubMed]

9. Erdmann, K.; Cheung, B.W.; Schroder, H. The possible roles of food-derived bioactive peptides in reducing the risk of cardiovascular disease. J. Nutr. Biochem. 2008, 19, 643-654. [CrossRef] [PubMed]

10. Kwon, D.Y.; Daily, J.W., III; Kim, H.J.; Park, S. Antidiabetic effects of fermented soybean products on type 2 diabetes. Nutr. Res. 2010, 30, 1-13. [CrossRef] [PubMed]

11. De Mejia, E.G.; de Lumen, B.O. Soybean bioactive peptides: A new horizon in preventing chronic diseases. Sex. Reprod. Menop. 2006, 4, 91-95. [CrossRef] 
12. Wang, W.; Dia, V.P.; Vasconez, M.; de Mejia, E.G.; Nelson, R.L. Analysis of soybean protein-derived peptides and the effect of cultivar, environmental conditions, and processing on lunasin concentration in soybean and soy products. J. AOAC Int. 2008, 91, 936-946. [PubMed]

13. Cam, A.; de Mejia, E.G. Role of dietary proteins and peptides in cardiovascular disease. Mol. Nutr. Food Res. 2012, 56, 53-66. [CrossRef] [PubMed]

14. Zarkadas, C.G.; Gagnon, C.; Poysa, V.; Khanizadeh, S.; Cober, E.R.; Chang, V.; Gleddie, S. Protein quality and identification of the storage protein subunits of tofu and null soybean genotypes, using amino acid analysis, one- and two-dimensional gel electrophoresis, and tandem mass spectrometry. Food Res. Int. 2007, 40, 111-128. [CrossRef]

15. Clarke, E.J.; Wiseman, J. Developments in plant breeding for improved nutritional quality of soya beans. I. Protein and amino acid content. J. Agric. Sci. 2000, 134, 111-124. [CrossRef]

16. Singh, B.P.; Vij, S.; Hati, S. Functional significance of bioactive peptides derived from soybean. Peptides 2014, 54, 171-179. [CrossRef] [PubMed]

17. Poysa, V.; Woodrow, L.; Yu, K. Effect of soy protein subunit composition on tofu quality. Food Res. Int. 2006, 39, 309-317. [CrossRef]

18. Maebuchi, M.; Samoto, M.; Kohno, M.; Ito, R.; Koikeda, T.; Hirotsuka, M.; Nakabou, Y. Improvement in the intestinal absorption of soy protein by enzymatic digestion to oligopeptide in healthy adult men. Food Sci. Technol. Res. 2007, 13, 45-53. [CrossRef]

19. Kostelac, D.; Rechkemmer, G.; Briviba, K. Phytoestrogens modulate binding response of estrogen receptors alpha and beta to the estrogen response element. J. Agric. Food Chem. 2003, 51, 7632-7635. [CrossRef] [PubMed]

20. Kelly, L.A. Phytoestrogens activate the estrogen receptor in HepG2 cells. Methods Mol. Biol. 2016, 1366, 445-455. [PubMed]

21. Vitale, D.C.; Piazza, C.; Melilli, B.; Drago, F.; Salomone, S. Isoflavones: Estrogenic activity, biological effect and bioavailability. Eur. J. Drug Metab. Pharmacokinet. 2013, 38, 15-25. [CrossRef] [PubMed]

22. Morito, K.; Hirose, T.; Kinjo, J.; Hirakawa, T.; Okawa, M.; Nohara, T.; Ogawa, S.; Inoue, S.; Muramatsu, M.; Masamune, Y. Interaction of phytoestrogens with estrogen receptors alpha and beta. Biol. Pharm. Bull. 2001, 24, 351-356. [CrossRef] [PubMed]

23. Song, W.O.; Chun, O.K.; Hwang, I.; Shin, H.S.; Kim, B.G.; Kim, K.S.; Lee, S.Y.; Shin, D.; Lee, S.G. Soy isoflavones as safe functional ingredients. J. Med. Food 2007, 10, 571-580. [CrossRef] [PubMed]

24. Messina, M. Soy and health update: Evaluation of the clinical and epidemiologic literature. Nutrients 2016, 8, 754. [CrossRef] [PubMed]

25. Zaheer, K.; Humayoun, A.M. An updated review of dietary isoflavones: Nutrition, processing, bioavailability and impacts on human health. Crit. Rev. Food Sci. Nutr. 2017, 57, 1280-1293. [CrossRef] [PubMed]

26. Wang, Q.; Ge, X.; Tian, X.; Zhang, Y.; Zhang, J.; Zhang, P. Soy isoflavone: The multipurpose phytochemical (Review). Biomed. Rep. 2013, 1, 697-701. [CrossRef] [PubMed]

27. Cederroth, C.R.; Nef, S. Soy, phytoestrogens and metabolism: A review. Mol. Cell. Endocrinol. 2009, 304, 30-42. [CrossRef] [PubMed]

28. Guang, C.; Chen, J.; Sang, S.; Cheng, S. Biological functionality of soyasaponins and soyasapogenols. J. Agric. Food Chem. 2014, 62, 8247-8255. [CrossRef] [PubMed]

29. Lule, V.K.; Garg, S.; Pophaly, S.D.; Hitesh; Tomar, S.K. Potential health benefits of lunasin: A multifaceted soy-derived bioactive peptide. J. Food Sci. 2015, 80, R485-R494. [CrossRef] [PubMed]

30. Aluko, R. (Ed.) Bioactive Peptides. In Functional Foods and Nutraceuticals; Springer: New York, NY, USA, 2012; pp. 37-61.

31. Shahidi, F.; Zhong, Y. Bioactive peptides. J. AOAC Int. 2008, 91, 914-931. [PubMed]

32. De Angelis, E.; Pilolli, R.; Bavaro, S.L.; Monaci, L. Insight into the gastro-duodenal digestion resistance of soybean proteins and potential implications for residual immunogenicity. Food Funct. 2017, 8, 1599-1610. [CrossRef] [PubMed]

33. Korhonen, H.; Pihlanto-Leppala, A.; Rantamaki, P.; Tupasela, T. Impact of processing on bioactive proteins and peptides. Trends Food Sci Technol. 1998, 9, 307-319. [CrossRef]

34. Wang, W.; De Mejia, E.G. A new frontier in soy bioactive peptides that may prevent age-related chronic diseases. Comp. Rev. Food Sci. Food Saf. 2005, 4, 63-78. [CrossRef] 
35. Fernandez-Orozco, R.; Frias, J.; Munoz, R.; Zielinski, H.; Piskula, M.K.; Kozlowska, H.; Vidal-Valverde, C. Fermentation as a bio-process to obtain functional soybean flours. J. Agric. Food Chem. 2007, 55, 8972-8979. [CrossRef] [PubMed]

36. Lammi, C.; Zanoni, C.; Arnoldi, A. IAVPGEVA, IAVPTGVA, and LPYP, three peptides from soy glycinin, modulate cholesterol metabolism in HepG2 cells through the activation of the LDLR-SREBP2 pathway. J. Funct. Foods 2015, 14, 469-478. [CrossRef]

37. Lammi, C.; Zanoni, C.; Arnoldi, A.; Vistoli, G. Two peptides from soy beta-Conglycinin Induce a hypocholesterolemic effect in HepG2 Cells by a statin-like mechanism: Comparative in vitro and in silico modeling studies. J. Agric. Food Chem. 2015, 63, 7945-7951. [CrossRef] [PubMed]

38. Kuba, M.; Tana, C.; Tawata, S.; Yasuda, M. Production of angiotensin I-converting enzyme inhibitory peptides from soybean protein with Monascus purpureus acid proteinase. Process Biochem. 2005, 40, 2191-2196. [CrossRef]

39. Yoshikawa, M. Bioactive peptides derived from natural proteins with respect to diversity of their receptors and physiological effects. Peptides 2015, 72, 208-225. [CrossRef] [PubMed]

40. Tsuruki, T.; Kishi, K.; Takahashi, M.; Tanaka, M.; Matsukawa, T.; Yoshikawa, M. Soymetide, an immunostimulating peptide derived from soybean beta-conglycinin, is an fMLP agonist. FEBS Lett. 2003, 540, 206-210. [CrossRef]

41. Tsuruki, T.; Yoshikawa, M. Design of soymetide-4 derivatives to potentiate the anti-alopecia effect. Biosci. Biotechnol. Biochem. 2004, 68, 1139-1141. [CrossRef] [PubMed]

42. Martinez-Villaluenga, C.; Rupasinghe, S.G.; Schuler, M.A.; Gonzalez de Mejia, E. Peptides from purified soybean beta-conglycinin inhibit fatty acid synthase by interaction with the thioesterase catalytic domain. FEBS J. 2010, 277, 1481-1493. [CrossRef] [PubMed]

43. Yamada, Y.; Muraki, A.; Oie, M.; Kanegawa, N.; Oda, A.; Sawashi, Y.; Kaneko, K.; Yoshikawa, M.; Goto, T.; Takahashi, N.; et al. Soymorphin-5, a soy-derived mu-opioid peptide, decreases glucose and triglyceride levels through activating adiponectin and PPARalpha systems in diabetic KKAy mice. Am. J. Physiol. Endocrinol. Metab. 2012, 302, E433-E440. [CrossRef] [PubMed]

44. Ohinata, K.; Agui, S.; Yoshikawa, M. Soymorphins, novel mu opioid peptides derived from soy beta-conglycinin beta-subunit, have anxiolytic activities. Biosci. Biotechnol. Biochem. 2007, 71, 2618-2621. [CrossRef] [PubMed]

45. Kaneko, K.; Iwasaki, M.; Yoshikawa, M.; Ohinata, K. Orally administered soymorphins, soy-derived opioid peptides, suppress feeding and intestinal transit via gut mu(1)-receptor coupled to 5-HT(1A), D.(2), and GABA(B.) systems. Am. J. Physiol. Gastrointest. Liver Physiol. 2010, 299, G799-G805. [CrossRef] [PubMed]

46. Nishi, T.; Hara, H.; Tomita, F. Soybean beta-conglycinin peptone suppresses food intake and gastric emptying by increasing plasma cholecystokinin levels in rats. J. Nutr. 2003, 133, 352-357. [CrossRef] [PubMed]

47. Nishi, T.; Hara, H.; Asano, K.; Tomita, F. The soybean beta-conglycinin beta 51-63 fragment suppresses appetite by stimulating cholecystokinin release in rats. J. Nutr. 2003, 133, 2537-2542. [CrossRef] [PubMed]

48. Nakajima, S.; Hira, T.; Eto, Y.; Asano, K.; Hara, H. Soybean beta 51-63 peptide stimulates cholecystokinin secretion via a calcium-sensing receptor in enteroendocrine STC-1 cells. Regul. Pept. 2010, 159, 148-155. [CrossRef] [PubMed]

49. Pak, V.V.; Koo, M.; Kwon, D.Y.; Yun, L. Design of a highly potent inhibitory peptide acting as a competitive inhibitor of HMG-CoA reductase. Amino Acids 2012, 43, 2015-2025. [CrossRef] [PubMed]

50. Pak, V.V.; Koo, M.S.; Kasymova, T.D.; Kwon, D.Y. Isolation and identification of peptides from soy 11S-Globulin with hypocholesterolemic activity. Chem. Nat. Comp. 2005, 41, 710-714. [CrossRef]

51. Pak, V.V.; Koo, M.; Lee, N.; Lee, J.S.; Kasimova, T.D.; Kwon, D.Y. Structure-activity relationship of Ile-Ala-Val-Pro peptide and its derivatives by using semi-empirical AM1 method. Chem. Nat. Comp. 2005, 41, 454-460. [CrossRef]

52. Lammi, C.; Zanoni, C.; Arnoldi, A.; Vistoli, G. Peptides derived from soy and lupin protein as dipeptidyl-peptidase IV inhibitors: In vitro biochemical screening and in silico molecular modeling Study. J. Agric. Food Chem. 2016, 64, 9601-9606. [CrossRef] [PubMed]

53. Yoshikawa, M.; Fujita, H.; Matoba, N.; Takenaka, Y.; Yamamoto, T.; Yamauchi, R.; Tsuruki, H.; Takahata, K. Bioactive peptides derived from food proteins preventing lifestyle-related diseases. Biofactors 2000, 12, 143-146. [CrossRef] [PubMed] 
54. Yoshikawa, M.; Kishi, K.; Takahashi, M.; Watanabe, A.; Miyamura, T.; Yamazaki, M.; Chiba, H. Immunostimulating peptide derived from soybean protein. Ann. N. Y. Acad. Sci. 1993, 685, 375-376. [CrossRef] [PubMed]

55. Kodera, T.; Nio, N. Identification of an angiotensin I-converting enzyme inhibitory peptides from protein hydrolysates by a soybean protease and the antihypertensive effects of hydrolysates in 4 spontaneously hypertensive model rats. J. Food Sci. 2006, 71, C164-C173. [CrossRef]

56. Pabona, J.M.; Dave, B.; Su, Y.; Montales, M.T.; de Lumen, B.O.; de Mejia, E.G.; Rahal, O.M.; Simmen, R.C. The soybean peptide lunasin promotes apoptosis of mammary epithelial cells via induction of tumor suppressor PTEN: Similarities and distinct actions from soy isoflavone genistein. Genes Nutr. 2013, 8, 79-90. [CrossRef] [PubMed]

57. Losso, J.N. The biochemical and functional food properties of the bowman-birk inhibitor. Crit. Rev. Food Sci. Nutr. 2008, 48, 94-118. [CrossRef] [PubMed]

58. Park, J.H.; Jeong, H.J.; Lumen, B.O. In vitro digestibility of the cancer-preventive soy peptides lunasin and BBI. J. Agric. Food Chem. 2007, 55, 10703-10706. [CrossRef] [PubMed]

59. Baturay, N.Z.; Roque, H. In vitro reduction of peroxidation in UVC-irradiated cell cultures by concurrent exposure with Bowman-Birk protease inhibitor. Teratog. Carcinog. Mutagen. 1991, 11, 195-202. [CrossRef] [PubMed]

60. Meyskens, F.L. Development of difluoromethyl-ornithine and Bowman-Birk inhibitor as chemopreventive agents by assessment of relevant biomarker modulation: some lessons learned. IARC Sci. Publ. 2001, 154, 49-55. [PubMed]

61. Kennedy, A.R.; Radner, B.S.; Nagasawa, H. Protease inhibitors reduce the frequency of spontaneous chromosome abnormalities in cells from patients with Bloom syndrome. Proc. Natl. Acad. Sci. USA 1984, 81, 1827-1830. [CrossRef] [PubMed]

62. Kennedy, A.R.; Wan, X.S. Effects of the Bowman-Birk inhibitor on growth, invasion, and clonogenic survival of human prostate epithelial cells and prostate cancer cells. Prostate 2002, 50, 125-133. [CrossRef] [PubMed]

63. Malkowicz, S.B.; McKenna, W.G.; Vaughn, D.J.; Wan, X.S.; Propert, K.J.; Rockwell, K.; Marks, S.H.; Wein, A.J.; Kennedy, A.R. Effects of Bowman-Birk inhibitor concentrate (BBIC) in patients with benign prostatic hyperplasia. Prostate 2001, 48, 16-28. [CrossRef] [PubMed]

64. Armstrong, W.B.; Kennedy, A.R.; Wan, X.S.; Taylor, T.H.; Nguyen, Q.A.; Jensen, J.; Thompson, W.; Lagerberg, W.; Meyskens, F.L., Jr. Clinical modulation of oral leukoplakia and protease activity by Bowman-Birk inhibitor concentrate in a phase IIa chemoprevention trial. Clin. Cancer Res. 2000, 6, 4684-4691. [PubMed]

65. Armstrong, W.B.; Kennedy, A.R.; Wan, X.S.; Atiba, J.; McLaren, C.E.; Meyskens, F.L., Jr. Single-dose administration of Bowman-Birk inhibitor concentrate in patients with oral leukoplakia. Cancer Epidemiol. Prev. Biomark. 2000, 9, 43-47.

66. Jiang, H.; Feng, J.; Du, Z.; Zhen, H.; Lin, M.; Jia, S.; Li, T.; Huang, X.; Ostenson, C.G.; Chen, Z. Oral administration of soybean peptide Vglycin normalizes fasting glucose and restores impaired pancreatic function in Type 2 diabetic Wistar rats. J. Nutr. Biochem. 2014, 25, 954-963. [CrossRef] [PubMed]

67. Inoue, N.; Nagao, K.; Sakata, K.; Yamano, N.; Gunawardena, P.E.; Han, S.Y.; Matsui, T.; Nakamori, T.; Furuta, H.; Takamatsu, K.; et al. Screening of soy protein-derived hypotriglyceridemic di-peptides in vitro and in vivo. Lipids Health Dis. 2011, 10, 85. [CrossRef] [PubMed]

68. Inoue, N.; Fujiwara, Y.; Kato, M.; Funayama, A.; Ogawa, N.; Tachibana, N.; Kohno, M.; Ikeda, I. Soybean beta-conglycinin improves carbohydrate and lipid metabolism in Wistar rats. Biosci. Biotechnol. Biochem. 2015, 79, 1528-1534. [CrossRef] [PubMed]

69. Kim, S.E.; Kim, H.H.; Kim, J.Y.; Kang, Y.I.; Woo, H.J.; Lee, H.J. Anticancer activity of hydrophobic peptides from soy proteins. Biofactors 2000, 12, 151-155. [CrossRef] [PubMed]

70. Draganidis, D.; Karagounis, L.G.; Athanailidis, I.; Chatzinikolaou, A.; Jamurtas, A.Z.; Fatouros, I.G. Inflammaging and skeletal muscle: Can protein intake make a difference? J. Nutr. 2016, 146, 1940-1952. [CrossRef] [PubMed]

71. Burris, R.L.; Ng, H.P.; Nagarajan, S. Soy protein inhibits inflammation-induced VCAM-1 and inflammatory cytokine induction by inhibiting the NF-kappaB and AKT signaling pathway in apolipoprotein E-deficient mice. Eur. J. Nutr. 2014, 53, 135-148. [CrossRef] [PubMed] 
72. Blum, A.; Lang, N.; Peleg, A.; Vigder, F.; Israeli, P.; Gumanovsky, M.; Lupovitz, S.; Elgazi, A.; Ben-Ami, M. Effects of oral soy protein on markers of inflammation in postmenopausal women with mild hypercholesterolemia. Am. Heart J. 2003, 145, e7. [CrossRef] [PubMed]

73. Greany, K.A.; Nettleton, J.A.; Wangen, K.E.; Thomas, W.; Kurzer, M.S. Consumption of isoflavone-rich soy protein does not alter homocysteine or markers of inflammation in postmenopausal women. Eur. J. Clin. Nutr. 2008, 62, 1419-1425. [CrossRef] [PubMed]

74. Tormala, R.; Appt, S.; Clarkson, T.B.; Mueck, A.O.; Seeger, H.; Mikkola, T.S.; Ylikorkala, O. Impact of soy supplementation on sex steroids and vascular inflammation markers in postmenopausal women using tibolone: Role of equol production capability. Climacteric 2008, 11, 409-415. [CrossRef] [PubMed]

75. Gu, Y.; Wu, J. LC-MS/MS coupled with QSAR modeling in characterising of angiotensin I-converting enzyme inhibitory peptides from soybean proteins. Food Chem. 2013, 141, 2682-2690. [CrossRef] [PubMed]

76. Tsou, M.J.; Kao, F.J.; Lu, H.C.; Kao, H.C.; Chiang, W.D. Purification and identification of lipolysis-stimulating peptides derived from enzymatic hydrolysis of soy protein. Food Chem. 2013, 138, 1454-1460. [CrossRef] [PubMed]

77. Shin, Z.I.; Yu, R.; Park, S.A.; Chung, D.K.; Ahn, C.W.; Nam, H.S.; Kim, K.S.; Lee, H.J. His-His-Leu, an angiotensin I converting enzyme inhibitory peptide derived from Korean soybean paste, exerts antihypertensive activity in vivo. J. Agric. Food Chem. 2001, 49, 3004-3009. [CrossRef] [PubMed]

78. Kim, H.J.; Bae, I.Y.; Ahn, C.W.; Lee, S.; Lee, H.G. Purification and identification of adipogenesis inhibitory peptide from black soybean protein hydrolysate. Peptides 2007, 28, 2098-2103. [CrossRef] [PubMed]

79. Dia, V.P.; Bringe, N.A.; de Mejia, E.G. Peptides in pepsin-pancreatin hydrolysates from commercially available soy products that inhibit lipopolysaccharide-induced inflammation in macrophages. Food Chem. 2014, 152, 423-431. [CrossRef] [PubMed]

80. Tomatsu, M.; Shimakage, A.; Shinbo, M.; Yamada, S.; Takahashi, S. Novel angiotensin I-converting enzyme inhibitory peptides derived from soya milk. Food Chem. 2013, 136, 612-616. [CrossRef] [PubMed]

81. Hernandez-Ledesma, B.; Amigo, L.; Ramos, M.; Recio, I. Angiotensin converting enzyme inhibitory activity in commercial fermented products. Formation of peptides under simulated gastrointestinal digestion. J. Agric. Food Chem. 2004, 52, 1504-1510. [CrossRef] [PubMed]

82. Nakahara, T.; Sano, A.; Yamaguchi, H.; Sugimoto, K.; Chikata, H.; Kinoshita, E.; Uchida, R. Antihypertensive effect of peptide-enriched soy sauce-like seasoning and identification of its angiotensin I-converting enzyme inhibitory substances. J. Agric. Food Chem. 2010, 58, 821-827. [CrossRef] [PubMed]

83. Nakahara, T.; Sugimoto, K.; Sano, A.; Yamaguchi, H.; Katayama, H.; Uchida, R. Antihypertensive mechanism of a peptide-enriched soy sauce-like seasoning: the active constituents and its suppressive effect on renin-angiotensin-aldosterone system. J. Food Sci. 2011, 76, H201-H206. [CrossRef] [PubMed]

84. Kwon, D.Y.; Oh, S.W.; Lee, J.S.; Yang, H.J.; Lee, S.H.; Lee, J.H.; Lee, Y.B.; Sohn, H.S. Amino acid substitution of hypocholesterolemic peptides originated from glycinin hydrolyzate. Food Sci. Biotechnol. 2002, 11, 55-61.

85. Choi, S.K.; Adachi, M.; Utsumi, S. Improved bile acid-binding ability of soybean glycinin A1a polypeptide by the introduction of a bile acid-binding peptide (VAWWMY). Biosci. Biotechnol. Biochem. 2004, 68, 1980-1983. [CrossRef] [PubMed]

86. Nagaoka, S.; Nakamura, A.; Shibata, H.; Kanamaru, Y. Soystatin (VAWWMY), a novel bile acid-binding peptide, decreased micellar solubility and inhibited cholesterol absorption in rats. Biosci. Biotechnol. Biochem. 2010, 74, 1738-1741. [CrossRef] [PubMed]

87. Choi, S.K.; Adachi, M.; Utsumi, S. Identification of the bile acid-binding region in the soy glycinin A1aB1b subunit. Biosci. Biotechnol. Biochem. 2002, 66, 2395-2401. [CrossRef] [PubMed]

88. Cho, S.J.; Juillerat, M.A.; Lee, C.H. Identification of LDL-receptor transcription stimulating peptides from soybean hydrolysate in human hepatocytes. J. Agric. Food Chem. 2008, 56, 4372-4376. [CrossRef] [PubMed]

89. Martinez-Villaluenga, C.; Bringe, N.A.; Berhow, M.A.; Gonzalez de, M.E. Beta-conglycinin embeds active peptides that inhibit lipid accumulation in 3T3-L1 adipocytes in vitro. J. Agric. Food Chem. 2008, 56, 10533-10543. [CrossRef] [PubMed]

90. Martinez-Villaluenga, C.; Dia, V.P.; Berhow, M.; Bringe, N.A.; Gonzalez de, M.E. Protein hydrolysates from beta-conglycinin enriched soybean genotypes inhibit lipid accumulation and inflammation in vitro. Mol. Nutr. Food Res. 2009, 53, 1007-1018. [CrossRef] [PubMed] 
91. Tsou, M.J.; Lin, S.B.; Chao, C.H.; Chiang, W.D. Enhancing the lipolysis-stimulating activity of soy protein using limited hydrolysis with Flavourzyme and ultrafiltration. Food Chem. 2012, 134, 1564-1570. [CrossRef] [PubMed]

92. Lammi, C.; Zanoni, C.; Arnoldi, A. Three peptides from soy glycinin modulate glucose metabolism in human hepatic HepG2 cells. Int. J. Mol. Sci. 2015, 16, 27362-27370. [CrossRef] [PubMed]

93. Nordentoft, I.; Jeppesen, P.B.; Hong, J.; Abudula, R.; Hermansen, K. Increased insulin sensitivity and changes in the expression profile of key insulin regulatory genes and beta cell transcription factors in diabetic KKAy-mice after feeding with a soy bean protein rich diet high in isoflavone content. J. Agric. Food Chem. 2008, 56, 4377-4385. [CrossRef] [PubMed]

94. Lu, M.P.; Wang, R.; Song, X.; Chibbar, R.; Wang, X.; Wu, L.; Meng, Q.H. Dietary soy isoflavones increase insulin secretion and prevent the development of diabetic cataracts in streptozotocin-induced diabetic rats. Nutr. Res. 2008, 28, 464-471. [CrossRef] [PubMed]

95. Cederroth, C.R.; Vinciguerra, M.; Gjinovci, A.; Kuhne, F.; Klein, M.; Cederroth, M.; Caille, D.; Suter, M.; Neumann, D.; James, R.W.; et al. Dietary phytoestrogens activate AMP-activated protein kinase with improvement in lipid and glucose metabolism. Diabetes 2008, 57, 1176-1185. [CrossRef] [PubMed]

96. Taniguchi, A.; Yamanaka-Okumura, H.; Nishida, Y.; Yamamoto, H.; Taketani, Y.; Takeda, E. Natto and viscous vegetables in a Japanese style meal suppress postprandial glucose and insulin responses. Asia Pac. J. Clin. Nutr. 2008, 17, 663-668. [PubMed]

97. Fujita, H.; Yamagami, T. Fermented soybean-derived Touchi-extract with anti-diabetic effect via alpha-glucosidase inhibitory action in a long-term administration study with KKAy mice. Life Sci. 2001, 70, 219-227. [CrossRef]

98. Kim, D.J.; Jeong, Y.J.; Kwon, J.H.; Moon, K.D.; Kim, H.J.; Jeon, S.M.; Lee, M.K.; Park, Y.B.; Choi, M.S. Beneficial effect of chungkukjang on regulating blood glucose and pancreatic beta-cell functions in C75BL/KsJ- $d b / d b$ mice. J. Med. Food 2008, 11, 215-223. [CrossRef] [PubMed]

99. Jamilian, M.; Asemi, Z. The effect of soy intake on metabolic profiles of women with gestational diabetes mellitus. J. Clin. Endocrinol. Metab. 2015, 100, 4654-4661. [CrossRef] [PubMed]

100. Oliva, M.E.; Chicco, A.; Lombardo, Y.B. Mechanisms underlying the beneficial effect of soy protein in improving the metabolic abnormalities in the liver and skeletal muscle of dyslipemic insulin resistant rats. Eur. J. Nutr. 2015, 54, 407-419. [CrossRef] [PubMed]

101. Tachibana, N.; Yamashita, Y.; Nagata, M.; Wanezaki, S.; Ashida, H.; Horio, F.; Kohno, M. Soy beta-conglycinin improves glucose uptake in skeletal muscle and ameliorates hepatic insulin resistance in Goto-Kakizaki rats. Nutr. Res. 2014, 34, 160-167. [CrossRef] [PubMed]

102. Roblet, C.; Doyen, A.; Amiot, J.; Pilon, G.; Marette, A.; Bazinet, L. Enhancement of glucose uptake in muscular cell by soybean charged peptides isolated by electrodialysis with ultrafiltration membranes (EDUF): activation of the AMPK pathway. Food Chem. 2014, 147, 124-130. [CrossRef] [PubMed]

103. Okamoto, A.; Hanagata, H.; Matsumoto, E.; Kawamura, Y.; Koizumi, Y.; Yanagida, F. Angiotensin I converting enzyme inhibitory activities of various fermented foods. Biosci. Biotechnol. Biochem. 1995, 59, 1147-1149. [CrossRef] [PubMed]

104. Okamoto, A.; Hanagata, H.; Kawamura, Y.; Yanagida, F. Anti-hypertensive substances in fermented soybean, natto. Plant Foods Hum. Nutr. 1995, 47, 39-47. [CrossRef] [PubMed]

105. Gibbs, B.F.; Zougman, A.; Masse, R.; Mulligan, C. Production and characterization of bioactive peptides from soy hydrolysate and soy-fermented food. Food Res. Int. 2004, 37, 123-131. [CrossRef]

106. Kuba, M.; Tanaka, K.; Tawata, S.; Takeda, Y.; Yasuda, M. Angiotensin I-converting enzyme inhibitory peptides isolated from tofuyo fermented soybean food. Biosci. Biotechnol. Biochem. 2003, 67, 1278-1283. [CrossRef] [PubMed]

107. Nishibori, N.; Kishibuchi, R.; Morita, K. Soy pulp extract inhibits angiotensin I-converting enzyme (ACE) Activity In vitro: evidence for its potential hypertension-improving action. J. Diet. Suppl. 2017, 14, 241-251. [CrossRef] [PubMed]

108. Kennedy, A.R. The Bowman-Birk inhibitor from soybeans as an anticarcinogenic agent. Am. J. Clin. Nutr. 1998, 68, 1406S-1412S. [CrossRef] [PubMed]

109. Lin, L.L.; Mick, R.; Ware, J.; Metz, J.; Lustig, R.; Vapiwala, N.; Rengan, R.; Kennedy, A.R. Phase I randomized double-blind placebo-controlled single-dose safety studies of Bowman-Birk inhibitor concentrate. Oncol. Lett. 2014, 7, 1151-1158. [CrossRef] [PubMed] 
110. Souza, L.C.; Camargo, R.; Demasi, M.; Santana, J.M.; de Sa, C.M.; de Freitas, S.M. Effects of an anticarcinogenic Bowman-Birk protease inhibitor on purified $20 \mathrm{~S}$ proteasome and MCF-7 breast cancer cells. PLOS ONE 2014, 9, e86600. [CrossRef] [PubMed]

111. Fereidunian, A.; Sadeghalvad, M.; Oscoie, M.O.; Mostafaie, A. Soybean Bowman-Birk protease inhibitor (BBI): Identification of the mechanisms of BBI suppressive effect on growth of two adenocarcinoma cell lines: AGS and HT29. Arch. Med. Res. 2014, 45, 455-461. [CrossRef] [PubMed]

112. Cruz-Huerta, E.; Fernandez-Tome, S.; Arques, M.C.; Amigo, L.; Recio, I.; Clemente, A.; Hernandez-Ledesma, B. The protective role of the Bowman-Birk protease inhibitor in soybean lunasin digestion: The effect of released peptides on colon cancer growth. Food Funct. 2015, 6, 2626-2635. [CrossRef] [PubMed]

113. Mehdad, A.; Brumana, G.; Souza, A.A.; Barbosa, J.; Ventura, M.M.; de Freitas, S.M. A Bowman-Birk inhibitor induces apoptosis in human breast adenocarcinoma through mitochondrial impairment and oxidative damage following proteasome $20 \mathrm{~S}$ inhibition. Cell Death Discov. 2016, 2, 15067. [CrossRef] [PubMed]

114. Galvez, A.F.; Chen, N.; Macasieb, J.; de Lumen, B.O. Chemopreventive property of a soybean peptide (lunasin) that binds to deacetylated histones and inhibits acetylation. Cancer Res. 2001, 61, 7473-7478. [PubMed]

115. Jeong, H.J.; Jeong, J.B.; Kim, D.S.; de Lumen, B.O. Inhibition of core histone acetylation by the cancer preventive peptide lunasin. J. Agric. Food Chem. 2007, 55, 632-637. [CrossRef] [PubMed]

116. Jeong, H.J.; Park, J.H.; Lam, Y.; de Lumen, B.O. Characterization of lunasin isolated from soybean. J. Agric. Food Chem. 2003, 51, 7901-7906. [CrossRef] [PubMed]

117. Lam, Y.; Galvez, A.; de Lumen, B.O. Lunasin suppresses E1A-mediated transformation of mammalian cells but does not inhibit growth of immortalized and established cancer cell lines. Nutr. Cancer 2003, 47, 88-94. [CrossRef] [PubMed]

118. Hernandez-Ledesma, B.; Hsieh, C.C.; de Lumen, B.O. Antioxidant and anti-inflammatory properties of cancer preventive peptide lunasin in RAW 264.7 macrophages. Biochem. Biophys. Res. Commun. 2009, 390, 803-808. [CrossRef] [PubMed]

119. Fernandez-Tome, S.; Ramos, S.; Cordero-Herrera, I.; Recio, I.; Goya, L.; Hernandez-Ledesma, B. In vitro chemo-protective effect of bioactive peptide lunasin against oxidative stress in human HepG2 cells. Food Res. Int. 2014, 62, 793-800. [CrossRef]

120. Cam, A.; de Mejia, E.G. RGD-peptide lunasin inhibits Akt-mediated NF-kappaB activation in human macrophages through interaction with the alphaVbeta3 integrin. Mol. Nutr. Food Res. 2012, 56, 1569-1581. [CrossRef] [PubMed]

121. Dia, V.P.; Torres, S.; de Lumen, B.O.; Erdman, J.W., Jr.; de Mejia, E.G. Presence of lunasin in plasma of men after soy protein consumption. J. Agric. Food Chem. 2009, 57, 1260-1266. [CrossRef] [PubMed]

122. Kong, X.; Guo, M.; Hua, Y.; Cao, D.; Zhang, C. Enzymatic preparation of immunomodulating hydrolysates from soy proteins. Bioresour. Technol. 2008, 99, 8873-8879. [CrossRef] [PubMed] 